\title{
Neuroprotective Effect of Agmatine in Mouse Spinal Cord Injury Model: Modulation by Imidazoline Receptors
}

\author{
Madhura P. Dixit' ${ }^{1}$, Manoj A. Upadhyaa ${ }^{1,2}$, Brijesh G. Taksande', Prachi Raut' ${ }^{1}$, Milind J. Umekar ${ }^{1}$, Nandkishor R. Kotagale ${ }^{1,3}$ \\ 'Department of Pharmacology, Division of Neuroscience, Shrimati Kishoritai Bhoyar College of Pharmacy, Nagpur, ${ }^{2}$ Department of Biology, Neuroscience Lab, Indian \\ Institute of Science Education and Research, Pune, ${ }^{3}$ Department of Pharmacology, Government College of Pharmacy, Amravati, Maharashtra, India
}

\section{Abstract}

Objective: The involvement of imidazoline receptors in the effect of agmatine was studied in locomotor recovery following experimental SCI (ESCI) in mice. Methods: ESCI was induced in mice using compression method. Locomotor function score (0-10) was measured on day 14 following ESCI. Results: Agmatine $(2.5,5$, and $10 \mathrm{mg} / \mathrm{kg}$ ) treatment through intraperitoneal route for 14 days following ESCI, dose-dependently improved the motor function score. Clonidine $(0.1 \mathrm{mg} / \mathrm{kg}$; imidazoline I1 receptor agonist) or moxonidine $(0.5 \mathrm{mg} / \mathrm{kg}$; I2 receptor agonist) treatment $15 \mathrm{~min}$ before agmatine $(2.5 \mathrm{mg} / \mathrm{kg})$ daily for 14 days, following ESCI, significantly potentiated the effect of per se agmatine. On the other hand, $15 \mathrm{~min}$ before treatment of efaroxan (1 mg/kg; imidazoline I1 receptor antagonist) or idazoxan (3 mg/kg; imidazoline 12 receptor antagonist) significantly blocked the motor function score of agmatine (10 $\mathrm{mg} / \mathrm{kg})$. Conclusion: These data suggest that imidazoline receptors may modulate the locomotor recovery following ESCI in agmatine treated mice, perhaps through I1/I2 receptors.

Keywords: Agmatine, imidazoline receptors, locomotor recovery, motor function score, spinal cord injury

\section{INTRODUCTION}

Spinal cord injury often results in disability or loss of movement and sensation below the site of injury. At present, few treatments for spinal cord injury are available, however with less significant functional improvement. Agmatine, an endogenous amine, exists in mammalian brain and has been proposed as a novel neurotransmitter/neuromodulator. ${ }^{[1]}$ The distribution of agmatine-containing neurons is concentrated in regions of the brain that subserve visceral and neuroendocrine control, processing of emotions, pain perception, cognition, and memory. Agmatine has been implicated in several biological processes such as neuroprotection, ${ }^{[2]}$ antinociception, ${ }^{[3]}$ convulsions, ${ }^{[4]}$ stress,${ }^{[5]}$ depression,,${ }^{[6]}$ and anxiety. ${ }^{[7]}$ It is interesting to note that agmatine also dose-dependently attenuates neuropathic pain in rodents. ${ }^{[8]}$ Its intraperitoneal administration reversed long-lasting hypersensitivity, hyperalgesia, and allodynia induced by neuropathic pain. ${ }^{[9-11]}$ Further, agmatine also attenuated the pain associated with diabetic neuropathy. ${ }^{[3,11,12]}$ Its peripheral administration enhanced morphine analgesia dose-dependently in neuropathic rats. ${ }^{[13]}$ Moreover, systemically administered agmatine significantly reduces the mechanical and thermal hyperalgesia

\begin{tabular}{|l|l|}
\hline \multicolumn{2}{|c|}{ Access this article online } \\
\hline Quick Response Code: & Website: \\
\hline & www.jnsbm.org \\
\hline & \\
\hline
\end{tabular}

as well as allodynia in neuropathic mice caused by spinal cord injury.

Agmatine binds to several target receptors such as imidazoline, N-methyl-D-aspartate (NMDA), nicotinic cholinergic, $\alpha_{2}$-adrenergic, serotonergic receptors, and inhibits nitric oxide synthase. Agmatine is co-localized with imidazoline receptor in several brain areas. Moreover, several pharmacological effects of agmatine are mediated through imidazoline receptors. The role of imidazoline receptor in nociception is fairly well established. Imidazoline binding sites have currently attracted attention in nociception as well as drug addiction. ${ }^{[14]}$ Moreover, the brain structures involved in the drug abuse and pain perception including hypothalamus, hippocampus, and amygdala are rich in imidazoline binding sites and its endogenous ligands. ${ }^{[15]}$ Imidazoline binding sites are a family

Address for correspondence: Nandkishor R. Kotagale, Department of Pharmacology, Division of Neuroscience, Shrimati Kishoritai Bhoyar College of Pharmacy, New Kamptee,

Nagpur - 441 002, Maharashtra, India. E-mail: nandukotagale@gmail.com

This is an open access journal, and articles are distributed under the terms of the Creative Commons Attribution-NonCommercial-ShareAlike 4.0 License, which allows others to remix, tweak, and build upon the work non-commercially, as long as appropriate credit is given and the new creations are licensed under the identical terms.

For reprints contact: reprints@medknow.com

How to cite this article: Dixit MP, Upadhya MA, Taksande BG, Raut P, Umekar MJ, Kotagale NR. Neuroprotective effect of agmatine in mouse spinal cord injury model: Modulation by imidazoline receptors. J Nat Sc Biol Med 2018;9:115-20. 
of unique nonadrenergic high-affinity binding sites that exist in three major subclasses (I1, I2, and I3) based on their ligand selectivity, subcellular distribution, and physiological functions ${ }^{[16,17]}$ Several imidazoline receptor agonists including moxonidine, clonidine, and antagonist idazoxan, efaroxan possess antinociceptive activity. ${ }^{[18]}$ Thus, in view of these preclinical evidence we hypothesized that agmatine-induced functional recovery from spinal cord injury might be mediated through imidazoline receptors.

\section{Materials And Methods}

\section{Animals}

Adult male Swiss-albino mice (22-27 g) were grouped house and given free access to food (Trimurty Feeds, Nagpur, India), and drinking water. They were maintained on a $12 \mathrm{~h}$ light/dark cycle, in controlled temperature $\left(25^{\circ} \mathrm{C} \pm 2^{\circ} \mathrm{C}\right)$ and relative humidity $(50 \%-70 \%)$. All experimental procedures were approved and carried out under strict compliance with Institutional Animal and Ethical Committee according to guidelines of the committee for the purpose of control and supervision of experiments on animals, ministry of environment and forests; Government of India; New Delhi.

\section{Drugs}

Following drugs were used Agmatine sulfate, clonidine (I1 imidazoline agonist), efaroxan (I1 imidazoline antagonist), moxonidine (I2 imidazoline agonist), and idazoxan (I2 imidazoline antagonist). Agmatine, moxonidine and efaroxan, idazoxan were obtained from Sigma Chemicals, St. Louise, USA. All drugs were dissolved in saline just before the experiments and administered through intraperitoneal route (i. p.) in a volume of $1 \mathrm{ml} / \mathrm{kg}$. Normal saline $(0.9 \% \mathrm{NaCl})$ was used as control.

\section{Surgery procedure for experimental spinal cord injury}

The method described and validated by others ${ }^{[19]}$ and our laboratory ${ }^{[20,21]}$ was employed for producing experimental SCI (ESCI) in mice. Mice were anesthetized with a mixture of ketamine $(50 \mathrm{mg} / \mathrm{kg})$, and xylazine $(10 \mathrm{mg} / \mathrm{kg})$ injected i. p. The thoracolumbar vertebral region was located and using the intra-scapular space as a reference point, the skin and subcutaneous tissues in the thoracic T10-12 region were incised. The paravertebral muscle fascia was penetrated, and muscles were peeled laterally using blunt dissection forceps. The T10-12 lamina was exposed, and a total laminectomy was performed without damaging the dura mater. Spinal cord injury (SCI) was achieved in each mouse by compressing the exposed spinal cord with a $5 \mathrm{~g}$ weight for $30 \mathrm{~s}$. In sham-operated mice, the above-mentioned procedure was carried out except that spinal cord compression was not performed. The incision was sutured layer to layer using chromic catgut sutures.

In the postoperative period, mice were treated with gentamicin $(40 \mathrm{mg} / \mathrm{kg}$ ) twice daily during the first 3 days as prophylaxis against urinary tract infection. Mice were also injected daily with $1 \mathrm{ml}$ lactated ringer subcutaneously for
10 days. Drinking water, softened chow, and regular pellets were provided ad libitum in the cages. Bladders were emptied manually twice a day until bladder function returned to normal.

\section{Assessment of locomotor recovery by hind limb motor} function scoring system for mouse

"Hindlimb motor function scoring system" was employed in the present study as mentioned. ${ }^{[19-24]}$ As described previously in our reports, ${ }^{[20,21]}$ this test includes monitoring the ability of mice to walk on bars of different widths. It permits detection of minor deficits that may be otherwise missed in open field and other test methods. The test is easy to perform and reproducible in our laboratory conditions. Individual animals were allowed to freely explore in open and well-illuminated arena $(0.7-0.9 \mathrm{~m})$, and observed for $1 \mathrm{~min}$. Parameters such as the movements in the hip, knee, and ankle joints, plantar placement, coordination between forelimbs and hind-limbs as well as weight bearing capacity were carefully observed and the performance of the mouse was scored accordingly. Briefly, the score 0 was given to the animals not showing any noticeable movement. The scores 1,2 , or 3 were given to the animals showing barely visible movement at any hind-limb joint (hip, knee, or ankle), movement of one or more hind-limb joints in one or both limbs, or animals showing alternate stepping and forward propulsive movements of the hind limbs, but no weight bearing, respectively. Scores 4 or 5 were given to the animals showing the ability to bear weight on their hind limbs and could walk with some deficit, or no deficit, respectively. The animals were scored $6,7,8,9$, or 10 if they were able to walk on bars of width $2,1.5,1,0.7$, or $0.5 \mathrm{~cm}$, respectively.

During the study, mortality was observed in some mice $(<8 \%)$ across the different groups, data from such animals were not considered for the statistical purpose.

\section{Treatment protocol}

\section{Effect of agmatine on spinal cord injury}

After spinal cord injury animals were injected with different doses of agmatine $(2.5,5,10 \mathrm{mg} / \mathrm{kg}$, i. p.) daily for 14 days between $9.00 \mathrm{~h}$ and $12.00 \mathrm{~h}$. Animals were observed for motor function score on day 14 of postinjury. Depending on the results of this experiment effective and subeffective dose of agmatine were determined to be used in following studies

\section{Effect of imidazoline receptors agonist on effect of agmatine in spinal cord injury}

In a separate group, animal exposed to SCI were injected with imidazoline I1 receptor agonist clonidine $(0.1 \mathrm{mg} / \mathrm{kg})$ or I2 receptor agonist moxonidine $(0.5 \mathrm{mg} / \mathrm{kg}) 15 \mathrm{~min}$ before subeffective dose of agmatine $(2.5 \mathrm{mg} / \mathrm{kg})$ daily for 14 days between $9.00 \mathrm{~h}$ and $12 \mathrm{~h}$ and observed for motor hind-limb score on day 14 of postsurgery.

\section{Effect of imidazoline receptors antagonist on effect of agmatine in spinal cord injury}

Additional group of animals exposed to SCI were injected with imidazolineI1 receptor antagonist efaroxan $(1 \mathrm{mg} / \mathrm{kg})$ or I2 receptor antagonist idazoxan $(3 \mathrm{mg} / \mathrm{kg})$ daily for 14 days 
Dixit, et al.: Imidazoline receptors modulates the neuroprotective effect of agmatine in SCI

$15 \mathrm{~min}$ before agmatine $(10 \mathrm{mg} / \mathrm{kg})$ between $9.00 \mathrm{~h}$ and $12 \mathrm{~h}$ and observed for motor hind-limb score on day 14 of postsurgery. The doses of agmatine and imidazoline receptor agonist or antagonist were selected on the basis of available literature and as confirmed in our preliminary findings.

\section{Statistical analysis}

All data were presented as the mean \pm standard error of the mean (SEM). The results of locomotor recovery in spinal cord injured mice and those of combinations were analyzed by one-way ANOVA followed by post hoc Bonferroni's multiple comparison's test. Results of statistical tests with $P<0.05$ were considered statistically significant.

\section{RESULTS}

\section{Effect of experimental spinal cord injury on motor function system}

Normal mice depicted the motor score of $10 \pm 0.2$. ESCI resulted in complete loss of movement of hind-limbs causing paraplegia in mice. The data of $24 \mathrm{~h}$ postsurgery showed significant decreased in the locomotor score $(2.5 \pm 0.5)$ as compared to sham-treated mice. On the other hand, sham-treated mice do not produce any sign of paraplegia and resembled same motor score as that of the normal mice. The locomotor score in ESCI mice was slightly improved on day 14 as compared to day $1(\mathrm{~F}[2,14]=62.24, P<0.001)$ but was significantly less $(P<0.001)$ as compared to normal animals [Figure 1].

\section{Effect of agmatine treatment in experimental spinal cord injury mice}

Agmatine treatment in the sham-treated mice showed same motor score as that of the normal mice $(P>0.05)$. On the other hand, chronic treatment of agmatine (5 and $10 \mathrm{mg} / \mathrm{kg}$, i. p.) starting from day 1 following ESCI progressively improved the locomotor score in mice as compared to saline-treated animals. Application of Bonferroni's multiple comparisons test revealed significant recovery of motor function on day 14 following surgery in 5 and $10 \mathrm{mg} / \mathrm{kg}$ dose of agmatine. However, its lower dose $(2.5 \mathrm{mg} / \mathrm{kg}$, i. p.) was found ineffective $(\mathrm{F}[4,24]=14.7$, $P<0.01)$. The results are depicted in Figure 2.

Effect of I1 agonist clonidine and agmatine combination in spinal cord injury

Figure 3 represents the interaction of I1 agonist clonidine and agmatine. Daily administration of subeffective dose combination of agmatine $(2.5 \mathrm{mg} / \mathrm{kg}$, i. p.) and I1 agonist clonidine $(0.1 \mathrm{mg} / \mathrm{kg}$, i. p. $)$ significantly improved the motor score as compared to their individual effect. The doses of agmatine and clonidine per se did not have effect on functional recovery of animal subjected to ESCI $(\mathrm{F}[4,24]=20.1, P<0.01)$.

Effect of 12 agonist moxonidine and agmatine combination in spinal cord injury

Chronic administration of subeffective dose combination of agmatine $(2.5 \mathrm{mg} / \mathrm{kg}$, i. p.) and $\mathrm{I} 2$ agonist moxonidine $(0.5 \mathrm{mg} / \mathrm{kg}$, i. p. $)$ significantly improved the motor score as

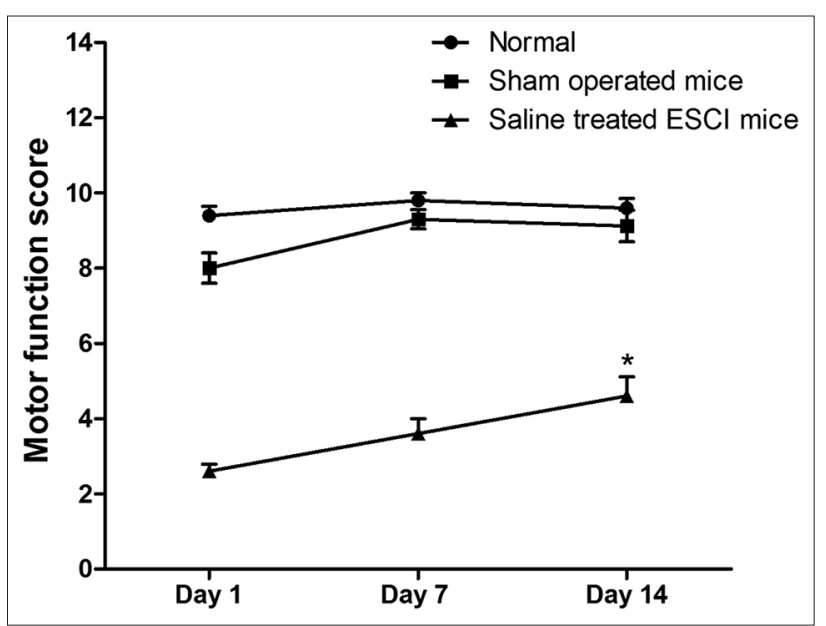

Figure 1: Effect of experimental spinal cord injury on locomotor function in mice. The locomotor recovery was monitored by motor function score of mice on days 1, 7 and 14 of experimental spinal cord injury. Data were represented as mean of MFS \pm standard error of the mean of 5 mice in each group. Data were analyzed by one-way ANOVA followed by post hoc Bonferroni's multiple comparisons test. ${ }^{*} P<0.001$ versus day 14 control

compared to their individual effect [Figure 4]. The doses of agmatine and moxonidine per se did not have any effect on functional recovery in ESCI-induced mice $(\mathrm{F}[4,24]=15.2$, $P<0.01)$.

Effect of 11 antagonist efaroxan on agmatine-induced functional recovery in spinal cord injury

Pretreatment of animal with I1 antagonist efaroxan $(1 \mathrm{mg} / \mathrm{kg}$, i. p.) before agmatine $(10 \mathrm{mg} / \mathrm{kg}$, i. p.) for day 14 significantly blocked the effect of agmatine on locomotor recovery in animal subjected to ESCI $(\mathrm{F}[4,24]=17.79, P<0.01)$. The dose of efaroxan per se did not have any effect on ESCI [Figure 5].

Effect of 12 antagonist idazoxan on agmatine-induced functional recovery in spinal cord injury

Treatment of animal with $\mathrm{I} 2$ antagonist idazoxan $(3 \mathrm{mg} / \mathrm{kg}$, i. p.) before agmatine $(10 \mathrm{mg} / \mathrm{kg}$, i. p.) for 14 days significantly attenuated the effect of agmatine on locomotor recovery in animal subjected to ESCI $(\mathrm{F}[4,24]=25.59, P<0.001)$. The dose of idazoxan used in the present study did not have any effect on ESCI [Figure 6].

\section{Discussion}

In the present study, we employed compression method for inducing SCI since, it mimics the typical human injury, wherein compression is caused by bony fragments or extruded disc material. ${ }^{[19]}$ While experimental injury inflicted at the T10-12 level resulted in hind-limb muscle paralysis, considerable recovery was noticed over a period of 14 days. ${ }^{[20,21]}$

The motor function score scale suggested by ${ }^{[19]}$ and used in our previous study ${ }^{[20,21]}$ was used to study the walking pattern of SCI in mice. The walking activity of each mouse was graded on the scale of $0-10$. Since, the test consists of observing the rat walking on the horizontal bars, minor deficits 


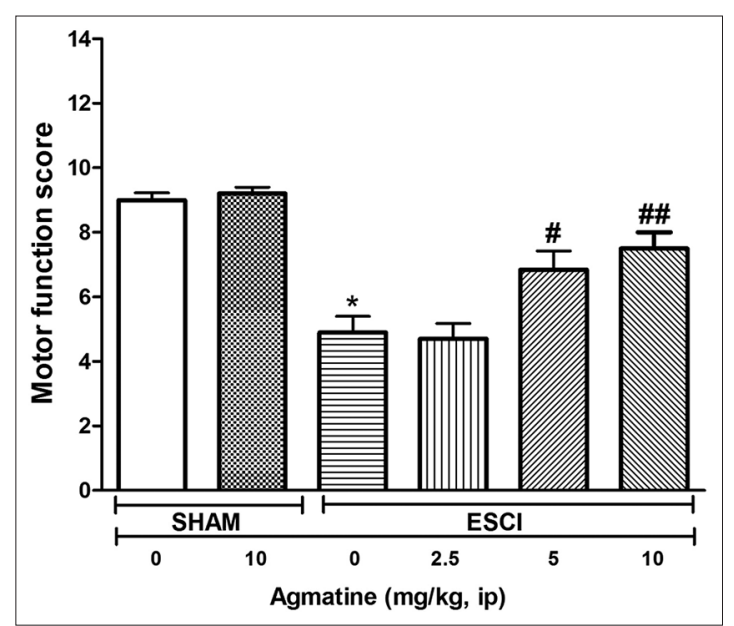

Figure 2: Effect of agmatine treatment on locomotor score in SHAM and spinal cord injured mice. The locomotor recovery was monitored by motor function score on day 14 of experimental spinal cord injury. Data were represented as mean of MFS + standard error of the mean of 5 mice in each group. Data were analyzed by one-way ANOVA followed by post hoc Bonferroni's multiple comparisons test. ${ }^{\star} P<0.001$ versus SHAM; ${ }^{\#} P<0.05,{ }^{\#} P<0.01$ versus experimental spinal cord injury per se

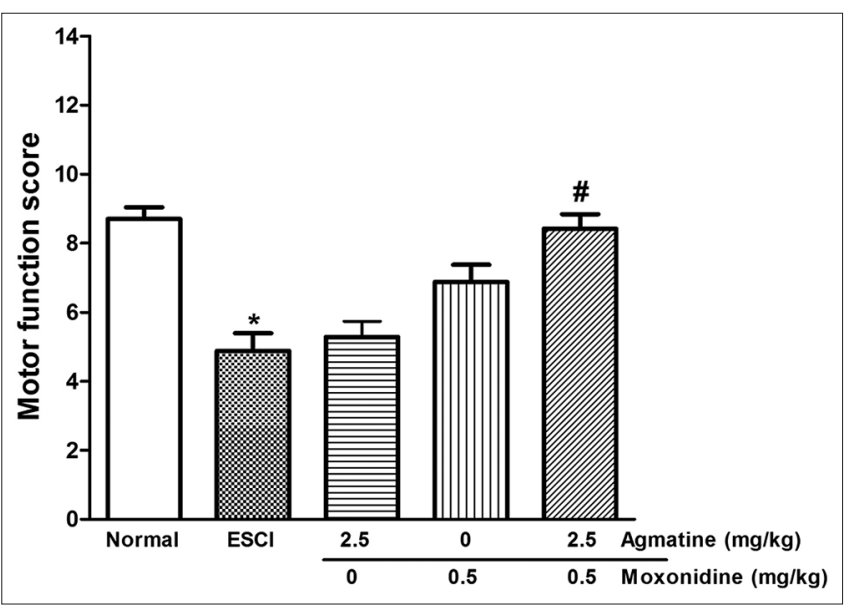

Figure 4: Effect of agmatine (2.5 mg/kg, i. p.) and moxonidine $(0.5 \mathrm{mg} / \mathrm{kg}$, i. p.) and their combination on locomotor recovery in spinal cord injured mice. Each mouse was subjected to the motor function score test on 14 days. Data were represented as mean of motor function score + standard error of the mean for 5 mice in each group. Data were analysed by one-way ANOVA followed by Bonferroni's multiple comparisons test. ${ }^{*} P<0.001$ versus Normal; ${ }^{\#} P<0.001$ versus agmatine

that are not easily detected in open field test can be readily revealed. Herein, mice subjected to ESCI showed significant locomotor recovery within 14 days. Saline treatment did not show any effect as compared to that of nontreated SCI mice. However, the observed change in the vehicle-treated mice is because of natural healing process and not due to vehicles. The improvement in the hind-limb function was observed with respect to movements of hind-limb joints and weight bearing. These results are in accordance with the previous findings where improved motor function was noticed in vehicle-treated SCI mice in similar time frame. ${ }^{[19-21,25]}$

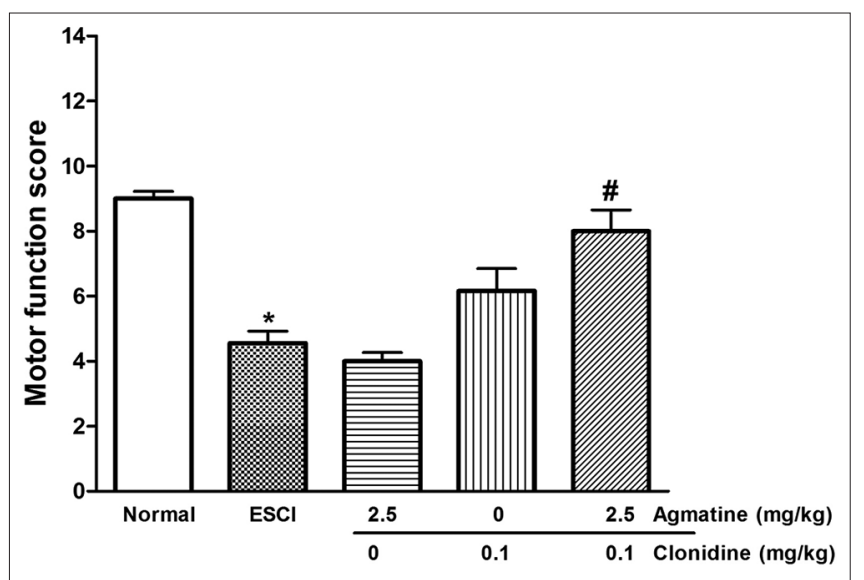

Figure 3: Effect of agmatine $(2.5 \mathrm{mg} / \mathrm{kg}$, i. p.) and clonidine $(0.1 \mathrm{mg} / \mathrm{kg}$, i. p.) and their combination on locomotor recovery in spinal cord injured mice. Each mouse was subjected to the motor function score test on day 14. Data were represented as mean of MFS + standard error of the mean for 5 mice in each group. Data were analysed by one-way ANOVA followed by post hoc Bonferroni's multiple comparisons test. ${ }^{\star} P<0.001$ versus normal; ${ }^{\#} P<0.001$ versus agmatine

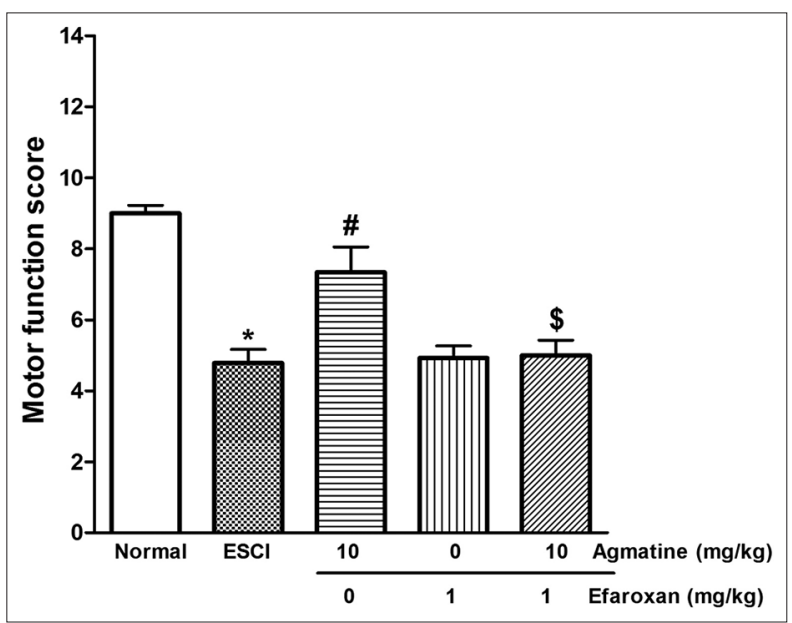

Figure 5: Effect of agmatine (10 mg/kg, i. p.) and efaroxan (1 mg/kg, i. p.) and their combination on locomotor recovery in spinal cord injured mice. Each mouse was subjected to the motor function score test on 14 days. Data were represented as mean of motor function score + standard error of the mean for 5 mice in each group. Data were analysed by one-way ANOVA followed by Bonferroni's multiple comparisons test. ${ }^{\star} P<0.001$ versus Normal; ${ }^{*} P<0.01$ versus experimental spinal cord injury; $\$ P<0.05$ versus agmatine

Agmatine treatment for 14 days also significantly improved the motor function score in mice as compared to the vehicle treatment. The results are in accordance with the previous finding where agmatine exhibited antinociceptive effect in neuropathic pain ${ }^{[3,8]}$ and also produced neuroprotection. ${ }^{[2]}$ Thus, suggesting the pivotal role of agmatine in functional recovery following ESCI.

It is now well accepted that imidazoline receptors play a potential role in mechanism and modulation of neuropathic pain signaling. ${ }^{[3,8]}$ Since agmatine exhibits antinociceptive 


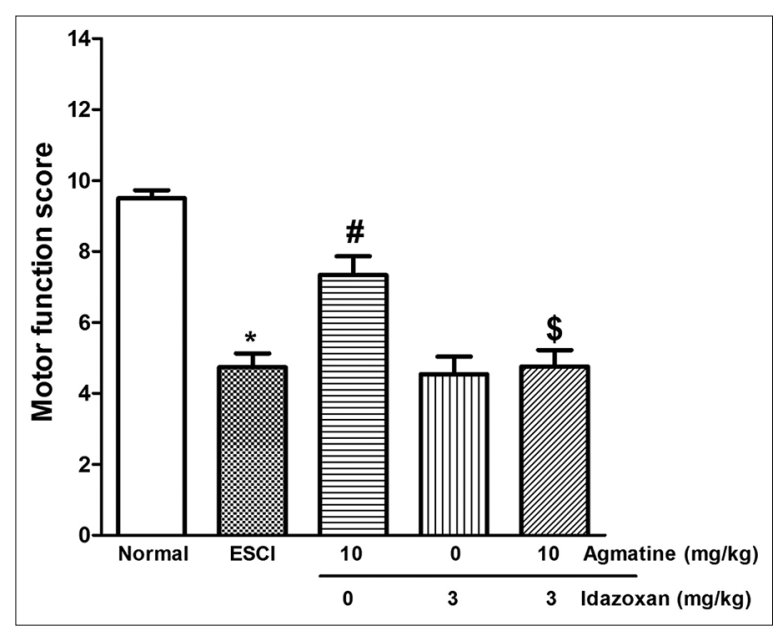

Figure 6: Effect of agmatine (10 mg/kg, i. p.) and idazoxan (3 mg/kg, i. p.) and their combination on locomotor recovery in spinal cord injured mice. Each mouse was subjected to the motor function score test on day 14. Data were represented as mean of motor function score + standard error of the mean for 5 mice in each group. Data were analysed by one-way ANOVA followed by Bonferroni's multiple comparisons test. ${ }^{\star} P<0.001$ versus Normal; ${ }^{*} P<0.01$ versus experimental spinal cord injury; $\$ P<0.01$ versus agmatine

action against neuropathic pain and shows affinity for imidazoline receptors. ${ }^{[2]}$ We investigated the involvement of imidazoline receptors in agmatine-induced functional recovery in SCI.

We found that the effect of agmatine on spinal cord injury was significantly potentiated by I1 agonist clonidine and I 2 agonist moxonidine. In contrast, it was completely blocked by pretreatment of animals with I1 antagonist efaroxan and I2 antagonist idazoxan. These results confirm our hypothesis that the beneficial effect of agmatine was mediated at least partly through imidazoline receptors.

Imidazoline binding sites have currently attracted attention in nociception. Selective imidazoline receptor agonists exhibit antinociceptive activity in animals. ${ }^{[1,26-28]}$ Antinociceptive activity from agmatine treatment could be expected because it binds to imidazoline. Several brain structures including hypothalamus, hippocampus, amygdala, etc., are rich in imidazoline binding sites and its endogenous ligands are involved in the drug abuse and pain perception. ${ }^{[15]}$ Imidazoline binding sites were a family of unique nonadrenergic high-affinity binding sites that exist in three major subclasses (I1, I2, and I3) based upon their ligand selectivity, subcellular distribution, and physiological functions. The I2 binding sites (I2A and I2B) are allosteric and were located on monoamine oxidases. Furthermore, the involvement of imidazoline I1/I2 endogenous ligands such as agmatine and $\beta$-carboline in nociception is now fairly well established. It is important to note that most of the agents used in present study shows considerable affinity toward $\alpha_{2}$-adrenergic receptors. Agmatine is a neurotransmitter with multi-receptor affinity. It acts as antagonist of NMDA and NOS inhibitors. Thus, the possibility of involvement of I1 and I 2 imidazoline receptors in the neuroprotective effect of agmatine cannot be ruled out.

In conclusion, spinal cord injury was developed by placing $5 \mathrm{~g}$ weight for $30 \mathrm{~s}$ at thoracic vertebra 10-12 segment. ESCI resulted in complete loss of movement of hind-limb in animals. Agmatine, a putative neurotransmitter improves the functional recovery in animal subjected to SCI. Imidazoline receptors agonist clonidine and moxonidine potentiated while antagonist's idazoxan and efaroxan blocked the effect of agmatine in SCI. Thus, the present study suggests that agmatine treatment showed locomotor recovery in SCI animal and this effect was possibly mediated through imidazoline receptors.

\section{Financial support and sponsorship}

Nil.

\section{Conflicts of interest}

There are no conflicts of interest.

\section{ReFEREnCES}

1. Reis DJ, Regunathan S. Is agmatine a novel neurotransmitter in brain? Trends Pharmacol Sci 2000;21:187-93.

2. Olmos G, DeGregorio-Rocasolano N, Paz Regalado M, Gasull T, Assumpció Boronat M, Trullas R, et al. Protection by imidazol (ine) drugs and agmatine of glutamate-induced neurotoxicity in cultured cerebellar granule cells through blockade of NMDA receptor. Br J Pharmacol 1999;127:1317-26.

3. Onal A, Delen Y, Ulker S, Soykan N. Agmatine attenuates neuropathic pain in rats: Possible mediation of nitric oxide and noradrenergic activity in the brainstem and cerebellum. Life Sci 2003;73:413-28.

4. Bence AK, Worthen DR, Stables JP, Crooks PA. An in vivo evaluation of the antiseizure activity and acute neurotoxicity of agmatine. Pharmacol Biochem Behav 2003;74:771-5.

5. Zhu MY, Wang WP, Cai ZW, Regunathan S, Ordway G. Exogenous agmatine has neuroprotective effects against restraint-induced structural changes in the rat brain. Eur J Neurosci 2008;27:1320-32.

6. Zomkowski AD, Hammes L, Lin J, Calixto JB, Santos AR, Rodrigues AL, et al. Agmatine produces antidepressant-like effects in two models of depression in mice. Neuroreport 2002;13:387-91.

7. Lavinsky D, Arteni NS, Netto CA. Agmatine induces anxiolysis in the elevated plus maze task in adult rats. Behav Brain Res 2003;141:19-24.

8. Onal A, Soykan N. Agmatine produces antinociception in tonic pain in mice. Pharmacol Biochem Behav 2001;69:93-7.

9. Laughlin LT, Reed GH. The monovalent cation requirement of rabbit muscle pyruvate kinase is eliminated by substitution of lysine for glutamate 117. Arch Biochem Biophys 1997;348:262-7.

10. Vanderah TW, Laughlin T, Lashbrook JM, Nichols ML, Wilcox GL, Ossipov MH, et al. Single intrathecal injections of dynorphin A or des-Tyr-dynorphins produce long-lasting allodynia in rats: Blockade by MK-801 but not naloxone. Pain 1996;68:275-81.

11. Fairbanks CA, Schreiber KL, Brewer KL, Yu CG, Stone LS, Kitto KF, et al. Agmatine reverses pain induced by inflammation, neuropathy, and spinal cord injury. Proc Natl Acad Sci U S A 2000;97:10584-9.

12. Karadag HC, Ulugol A, Tamer M, Ipci Y, Dokmeci I. Systemic agmatine attenuates tactile allodynia in two experimental neuropathic pain models in rats. Neurosci Lett 2003;339:88-90.

13. Kolesnikov Y, Jain S, Pasternak GW. Modulation of opioid analgesia by agmatine. Eur J Pharmacol 1996;296:17-22.

14. Lewis B, Wellmann KA, Barron S. Agmatine reduces balance deficits in a rat model of third trimester binge-like ethanol exposure. Pharmacol Biochem Behav 2007;88:114-21.

15. Ruggiero DA, Regunathan S, Wang H, Milner TA, Reis DJ. Immunocytochemical localization of an imidazoline receptor protein in the central nervous system. Brain Res 1998;780:270-93.

16. Michel MC, Insel PA. Are there multiple imidazoline binding sites? 
Trends Pharmacol Sci 1989;10:342-4.

17. Eglen RM, Hudson AL, Kendall DA, Nutt DJ, Morgan NG, Wilson VG, et al. 'Seeing through a glass darkly': Casting light on imidazoline 'I' sites. Trends Pharmacol Sci 1998;19:381-90.

18. Diaz A, Mayet S, Dickenson AH. BU-224 produces spinal antinociception as an agonist at imidazoline I2 receptors. Eur J Pharmacol 1997;333:9-15.

19. Farooque M. Spinal cord compression injury in the mouse: Presentation of a model including assessment of motor dysfunction. Acta Neuropathol 2000;100:13-22.

20. Bharne AP, Upadhya MA, Kokare DM, Subhedar NK. Effect of alpha-melanocyte stimulating hormone on locomotor recovery following spinal cord injury in mice: Role of serotonergic system. Neuropeptides 2011;45:25-31.

21. Bharne AP, Upadhya MA, Shelkar GP, Singru PS, Subhedar NK, Kokare DM, et al. Neuroprotective effect of cocaine- and amphetamine-regulated transcript peptide in spinal cord injury in mice. Neuropharmacology 2013;67:126-35.

22. Basso DM, Fisher LC, Anderson AJ, Jakeman LB, McTigue DM,
Popovich PG, et al. Basso mouse scale for locomotion detects differences in recovery after spinal cord injury in five common mouse strains. J Neurotrauma 2006;23:635-59.

23. Pajoohesh-Ganji A, Byrnes KR, Fatemi G, Faden AI. A combined scoring method to assess behavioral recovery after mouse spinal cord injury. Neurosci Res 2010;67:117-25.

24. Ung RV, Lapointe NP, Tremblay C, Larouche A, Guertin PA. Spontaneous recovery of hindlimb movement in completely spinal cord transected mice: A comparison of assessment methods and conditions. Spinal Cord 2007;45:367-79.

25. Isaksson J, Farooque M, Olsson Y. Improved functional outcome after spinal cord injury in iNOS-deficient mice. Spinal Cord 2005;43:167-70.

26. Paalzow L. Analgesia produced by clonidine in mice and rats. J Pharm Pharmacol 1974;26:361-3.

27. Browning S, Lawrence D, Livingston A, Morris B. Interactions of drugs active at opiate receptors and drugs active at alpha 2-receptors on various test systems. Br J Pharmacol 1982;77:487-91.

28. Ossipov MH, Suarez LJ, Spaulding TC. Antinociceptive interactions between pharmacostrategies. Cell Mol Life Sci 1989;64:2023-41. 